\title{
Migration as a factor in formation of the demographic potential of rural areas of the central black earth region
}

\author{
Evgeny Reutov, Viktor Zakharov, Dianna Khripkova* \\ Belgorod State National Research University, Belgorod, Russia
}

\begin{abstract}
The article studies migration as one of the factors in the formation of the demographic potential of rural areas. The purpose of the article is to identify key trends in migration processes occurring in rural areas of the regions of the Central Black Earth Economic Region, and to determine their impact on the demographic potential of rural areas. The empirical basis of the article was statistical data characterizing the migration movement of the population of rural areas of five regions of the Central Black Earth Economic Region, as well as the results of a series of semiformalized interviews (September-October 2019, N = 50 respondents) conducted as part of the research project "Mental Inequalities as a Factor of Social Polarization of the Russian Province". The analysis of statistical data made it possible to conclude that the migration attractiveness of rural areas in most regions of the Central Black Earth Region is quite high. However, optimism about the migration attractiveness of rural areas of the Central Black Earth Region and the positive role of migration processes in the formation and implementation of the demographic potential of rural areas is premature. First, the migration inflow to rural areas of the central black earth regions is quite differentiated. There are leading regions and outsiders. Second, the gender imbalance of the migration process indicates the predominance of the "non-family" nature of migration, which means that it has an unstable impact on the demographic potential of rural areas. Third, it can be assumed that even in the case of a positive balance of migration, the human potential of the rural areas of the regions of the Central Black Earth Region may deteriorate. Currently, the migration inflow has a pronounced gender imbalance and does not compensate for the natural decline in the population. Rural areas are mainly viewed by their inhabitants as less advantageous in terms of achieving success in life, the direct and indirect effects of which is the deterioration of the quality of the human potential of rural areas. In the best case, migration processes at the moment make it possible to reduce the intensity of the devaluation of the demographic potential of rural areas, and even then not in all regions of the Central Black Earth Region.
\end{abstract}

\footnotetext{
${ }^{*}$ Corresponding author: davtyan@,bsu.edu.ru
} 


\section{Introduction}

Depopulation is one of the most serious threats to Russia's national security. Presence of the world's largest territory and the length of external borders with a low population density and its uneven territorial distribution form a complex of imbalances in the socio-economic and geopolitical development of the country. Even for the minimum level of economic development of the territories of Siberia, the Far North and other spaces outside Central Russia and areas close to megacities, it is necessary to create and maintain industrial, engineering and social infrastructure, which is impossible without the availability of demographic resources.

Meanwhile, the demographic indicators of recent years clearly indicate the trend of depopulation that began in 2017 , caused by a complex of both demographic and socioeconomic factors, including economic stagnation, a long-term decline in household income and a sharp increase in mortality as a result of direct and indirect influence. pandemic coronavirus.

Table 1. Population of the Russian Federation.

\begin{tabular}{|c|c|c|c|c|}
\hline Jan. 1, 2017 & Jan. 1, 2018 & Jan. 1, 2019 & Jan. 1, 2020 & Jan. 1, 2021 \\
\hline 146804.4 & 146880.4 & 146780.7 & 146748.6 & 146171.0 \\
\hline
\end{tabular}

All of the above is directly related to the rural population of Russia. It is decreasing not only due to the outflow to cities, but also as a result of natural population decline. The result is the gradual degradation of many rural areas, the loss of their economic demographic potential, without which not only sustainable, but also any development in principle is impossible.

Table 2. The size of the rural population of the Russian Federation.

\begin{tabular}{|c|c|c|c|c|}
\hline Jan. 1,2017 & Jan. 1, 2018 & Jan. 1, 2019 & Jan. 1, 2020 & $\begin{array}{c}\text { Jan. 1, } \\
2021\end{array}$ \\
\hline 37772.0 & 37553.5 & 37327.12 & 37186.1 & $36,919.4$ \\
\hline
\end{tabular}

Rural territories of the regions of the Central Black Earth Economic Region are no exception, the population of which (with minor exceptions in certain periods) has been steadily decreasing in recent years.

Table 3. The size of the rural population in the regions of the Central Black Earth Economic Region.

\begin{tabular}{|c|c|c|c|c|c|}
\hline & Jan. 1, 2017 & Jan. 1, 2018 & Jan. 1, 2019 & Jan. 1, 2020 & $\begin{array}{c}\text { Jan. 1, } \\
2021\end{array}$ \\
\hline $\begin{array}{c}\text { Belgorod } \\
\text { Region }\end{array}$ & 507.9 & 505.4 & 503.626 & 503.633 & 499.949 \\
\hline $\begin{array}{c}\text { Voronezh } \\
\text { Region }\end{array}$ & 763.0 & 757.4 & 749.215 & 744.790 & 738.562 \\
\hline Kursk Region & 362.9 & 358.3 & 352.122 & 347.544 & 343.740 \\
\hline Lipetsk Region & 414.0 & 410.0 & 405.763 & 402.963 & 399.149 \\
\hline Tambov Region & 410.9 & 404.3 & 394.977 & 388.731 & 382.519 \\
\hline
\end{tabular}

Meanwhile, the rural territories of Russia, its individual regions and macroregions, including the Central Black Earth Economic Region, have an undoubted demographic potential, the full implementation of which can reverse the depopulation trend that is dangerous for the long-term development of society. Moreover, in the context of a pandemic crisis, extra-urban areas can become a resource for adaptation. N.E. Pokrovsky, A.Yu. Makshanchikova, E.A. Nikishin write: "The pandemic that hit megalopolises and 'global 
cities' has rapidly and noticeably destroyed the chains of social interactions and transformed the way of life of the townspeople into something different from the established patterns of everyday life. The modern "global city" - seemingly the pinnacle of the progress of civilization - turned out to be not at all as comfortable and safe as techno-optimists thought, it showed itself not as an impregnable bulwark of progress, but as a system, largely vulnerable to the effects of nature, in this case biological, it has become a victim of the "dark side" of urbanization. In scientific communities and the public sphere in general, the question of the possibility and prospects of designing "life after the city" is raised, namely, the problems of reverse migration and deurbanization as a special direction of the spatial movement of the population and the corresponding transformation of the way of life are being actualized" [1].

The demographic potential (from Latin potentia - strength, opportunity) of territories can be interpreted as a set of opportunities and conditions for their development lying in the sphere of population reproduction.

For the first time the concept of "demographic potential", according to some sources, was offered to be introduced by the English demographer R. Fisher in the 1920s. R. Fisher metaphorically considered the birth of a person as receiving life "on credit", and the subsequent birth of his/her own children as "paying off the debt". Therefore, the influence of the demographic potential on development of society, according to R. Fischer, was traced only in the narrowly demographic sphere and was reflected in the birth rate. Moreover, the concept already introduced by R. Fischer has not received precise indicators in the demographic and statistical sciences of his day. According to other sources, the concept of "demographic potential" was introduced by J. Stewart, who investigated the factors of migration. He borrowed the concept of "potential" from physics and, using the concept of "gravitational potential," believed that the interaction between masses of people is determined by connections similar to physical ones [2].

Later, in the study of migration processes in domestic science, the concept of "migration potential" prevailed, under which L.L. Rybakovsky and N.I. Kozhevnikov, for example, understood the "assessment of migration resources located in countries - possible donors for the recipient country" [2].

K.A. Kharchenko interpreting the concept of demographic potential indicates that: "The internal structure of demographic potential includes the potentials of fertility, selfpreservation behavior, a decrease in migration outflow and an increase in migration growth of the population. Wherein, it is hardly advisable to separate the migration potential from the demographic potential, as is done in a number of works" [3].

The concept of the demographic potential of the territory has significant methodological value, which, from the point of view of O.L. Rybakovsky and O.A. Tayunova is formed, on the one hand, under the influence of fertility and mortality processes, and on the other, migration: "the demographic potential of a territory is, firstly, the reproductive capabilities of the resident population of a given territory, including retention or changes in the levels and trends of fertility and mortality, and, secondly, the possibilities of the population of the regions associated with a given territory to change the size and structure of its population by migration" [4]. Also, these authors note the difference in measuring the demographic potential of the territory, depending on the methodology and purpose of its assessment: "depending on the time of assessment, the demographic potential can be either the level of demographic development achieved at the moment, or those opportunities that can be realized in the future" [4].

From the point of view of A.I. Kuzmin, "demographic potential as a synthetic category is not just the size or mass of the population of a country or a macroregion, but a certain system for assessing the potentials of its viability, marriage, fertility, divorce rate, the 
formation of sex, age and family and marriage structure and territorial mobility of the population (including pendulum migration)" [5].

M.L. Yashin and N.R. Aleksandrov offer to measure the demographic potential of Russian municipalities using indicators such as growth/decline in population, population size, share of the working-age population, fertility rate, growth/decline in fertility rate, mortality rate, dynamics of mortality rate, natural decline rate population, the coefficient of migration inflow/outflow of the population [6].

The concept of "demographic potential" is actively studied not only by domestic, but also by foreign researchers from various positions and points of view. For example, the Czech researcher, M. Obrębalski, in his papers, studies the demographic potential of cities in the Czech Republic and Poland from the position of a functional approach [7]. William Joe, Abhishek Kumar, Sunil Rajpal consider the demographic potential in the context of its connection with the economic development of India [8]. Marta Rostropowicz-Miśko analyzes the role of female labor migration on the demographic potential of Poland [9].

From our point of view, for the calculation and comparative analysis of the demographic potential of territories, it is advisable to use such indicators as the share of the population of reproductive age, the birth rate and the coefficient of migration inflow/loss of the population. Thus, two key factors of population dynamics are indirectly taken into account - fertility and migration.

In Russia, including in the overwhelming majority of its regions and in their rural territories, a demographic situation with a low birth rate and an orientation towards a small family has become entrenched as a consequence of the so-called demographic transition. In these conditions, the migration aspect of the demographic potential acquires special significance - presence and purposeful creation of conditions for the influx of the population, if possible, having a sufficient level of professional qualifications and socio-cultural identity with the host.

\section{Study Methods}

The purpose of this article is to identify the key trends in migration processes occurring in rural areas of the regions of the Central Black Earth Economic Region, and to determine their impact on the demographic potential of rural areas.

The empirical basis of the article is statistical data characterizing the migration movement of the population of rural areas of five regions of the Central Black Earth Economic Region, as well as the results of a series of semi-formalized interviews (September-October of 2019, $\mathrm{N}=50$ respondents) conducted as part of the research project "Mental Inequalities as a Factor of Social Polarization of the Russian Province" (headed by E.V. Reutov).

\section{Study Results}

Analysis of statistical data allows to conclude that the migration attractiveness of rural areas in most regions of the Central Black Earth Region is quite high. In 2020, four out of five regions -- Belgorod, Voronezh, Kursk and Lipetsk regions were characterized by migration growth of the population. The exception was the Tambov region, where a significant migration outflow was recorded. The Voronezh region became the leader in absolute migration growth, the rural population of which increased by 2707 people.

The structure of migration growth in all recipient regions was distinguished by a noticeable (on average, approximately two times) predominance of men; and in the only donor region, the Tambov Oblast, women also more than twice prevailed in the migration outflow (table). On the whole, this indicates a greater attractiveness of the regions of the 
Central Black Earth Region for men. The explanation here, most likely, lies in the specific nature of the labor resources demanded by the rural territories of the Central Black Earth Region. A significant share in the agro-industrial complex, on the one hand, of physical labor, and on the other, the demand for qualified organizational and managerial personnel, also represented by the majority of men, forms a corresponding gender imbalance in the migration flows of the population. However, if we consider the traditional shortage of men in rural areas, due to their higher mortality, then the migration gender imbalance as a whole has a positive effect on the reproduction of the demographic potential of rural areas in the regions of the Central Black Earth Region.

Table 4. Migration growth in 2020 in rural areas of the regions of the Central Black Earth Region.

\begin{tabular}{|c|c|c|c|}
\hline & \multicolumn{3}{|c|}{ Migration growth, people } \\
\hline & Men & Women & Total \\
\hline Belgorod Region & 1288 & 633 & 1951 \\
\hline Voronezh Region & 1765 & 942 & 2707 \\
\hline Kursk Region & 730 & 413 & 1143 \\
\hline Lipetsk Region & 668 & 202 & 870 \\
\hline Tambov Region & -405 & -940 & -1345 \\
\hline
\end{tabular}

Also, when analyzing statistical data, it is easy to notice that in two of the regions Voronezh and Lipetsk regions, the migration growth of the population of rural areas is higher than in the region as a whole. In the Lipetsk region, it almost made it possible to block the migration outflow of the population as a whole.

Table 5. Migration growth in 2020 in the regions of the Central Black Earth Region.

\begin{tabular}{|c|c|c|c|}
\hline & \multicolumn{3}{|c|}{ Migration growth, people } \\
\hline & Men & Women & Total \\
\hline Belgorod Region & 2422 & 1807 & 4229 \\
\hline Voronezh Region & -818 & 1682 & 866 \\
\hline Kursk Region & 1431 & 1499 & 2930 \\
\hline Lipetsk Region & -317 & -22 & -339 \\
\hline Tambov Region & -916 & -887 & -1803 \\
\hline
\end{tabular}

Nevertheless, optimism about the migration attractiveness of rural areas of the Central Black Earth Region and the positive role of migration processes in formation and implementation of the demographic potential of rural areas is premature. First, the migration inflow to rural areas of the central black earth regions is quite differentiated. There are leading regions, and there are outsiders, and their difference is due to the complex of socioeconomic and infrastructural conditions that form the migration attractiveness of rural areas and the region as a whole. Second, the gender imbalance of the migration process indicates the predominance of the "non-family" nature of migration, which means that it has an unstable impact on the demographic potential of rural areas. Third, it can be assumed that even in the case of a positive balance of migration, the human potential of the rural areas of the regions of the Central Black Earth Region may deteriorate. Thus, young people and the most qualified specialists leave them, and workers with lower qualifications and older age come.

In the course of interviews conducted in 2019, a fairly large part of rural respondents were skeptical about the possibility of self-realization in their native village. "Where do you think there are more chances to succeed, to achieve success in life - where you live or somewhere else?" - "Elsewhere" (woman, 30 years old, village, Belgorod region); "In the other place. Maybe in villages, small towns, at least some options, I hope, still exist. Well, it would be even more interesting in a big city" (woman, 50 years old, village, Voronezh 
region); "Of course, the city has more chances to achieve success in life. More opportunities to find yourself and in general ... Find a more prestigious job and study, of course. Actually, we have nowhere to get education" (woman, 42 years old, village, Voronezh region); "In the other place. You can't do it with here" (woman, 69 years old, village, Voronezh region); "Of course, in the city. You can already come to the village when you are already a professional in some area, for example, in the agricultural one. Then you can come and arrange your business or connect to what is already there. However, there is nothing to catch here yet "(woman, 72 years old, village, Voronezh region); "Well, how can you achieve much in a village with six yards. You need to study, get an education, go to a big city and look for a bride" (man, 50 years old, village, Belgorod region).

Only a small part of the respondents expressed their opinion that rural areas can be considered approximately equal in terms of chances for the implementation of strategies and tactics for achieving success in life, while paying attention to the socio-economic differentiation of regional development in Russia and to the difference in the criteria for the attractiveness of urban and rural territories: "You can absolutely everywhere. You can ... Well, of course, there are more options in the city. But you can do it here also. In general, it is easier to succeed where there are more people, because mainly people make money. In general, you can take 100 hectares in the village. Plant, grow, take to the city, or go to town. It is possible everywhere, if you wish. If there is no desire, then you will see nothing under your nose, do nothing" (man, 31 years old, village, Voronezh region); "Material well-being, of course, is more attainable in the centers - regional or capital. It is convenient to start a family and have children in a smaller settlement - where there is fresh air, where there is closeness to nature, where there is not such a large population, gas pollution and other delights of megacities" (woman, 56 years old, village, Voronezh region); "I must say it, of course, depends on the territory. Of course, in our Belgorod region, instead of birch (and what is birch, is firewood), instead of birch, we grow apple trees. Naturally, people will live better there, where apple and cherry trees grow, not birch and pine" (man, 75 years old, village, Belgorod region).

\section{Discussion of Study Results}

At present, the scientific discourse is extensively discussing the issue of the demographic potential of rural areas. It is considered as a resource for the strategic development of territories, as well as adaptation during the crisis caused by the coronavirus infection pandemic, as a condition for ensuring sustainable development of rural areas. Migration as a factor in the formation of demographic potential is also becoming the subject of research by many authors. For example, I.B. Magomedov [10] in his works examines the role of migration in the demographic development of European countries. M.A. Kartseva, N.V. Mkrtchyan and Yu.F. Florinskaya study the impact of migration on socio-demographic processes [11]. V.A. Lapshov explores migration as a resource for socio-economic development [12]. The approach of A.Yu. Lukyanova and A.V. Baranov presents undoubted scientific interest, where the authors consider migration as a determinant of personnel security in the region [13].

Wherein, in sociological and demographic science, studies devoted to the study of migration and its impact on the demographic potential of individual local territories, taking into account their cultural, economic, social specifics, are insufficiently developed; this is the problem that our study solves. 


\section{Conclusion}

Therefore, at present, the rural areas of most regions of the Central Black Earth Region have a more or less pronounced migration attractiveness (with the exception of the Tambov Region). However, the migration inflow has a pronounced gender imbalance and does not compensate for the natural decline in the population. Rural areas are mainly viewed by their inhabitants as less advantageous in terms of achieving success in life, the direct and indirect effects of which is the deterioration of the quality of the human potential of rural areas.

In the best case, migration processes at the moment make it possible to reduce the intensity of the devaluation of the demographic potential of rural areas, and even then not in all regions of the Central Black Earth Region.

To increase the role of migration in the formation and implementation of the demographic potential of rural areas, it is necessary to develop the social and engineering infrastructure of rural areas, create jobs, including on the basis of remote employment, create preferences for attracting young people and qualified specialists to the economy, including from abroad (within the framework of compatriot resettlement programs).

\section{Acknowledgment}

The study was carried out within the framework of the state assignment of the National Research University BelSU, project No. 0624-2020-0027 "Socio-Demographic Determinants of Development of Rural Areas of the Central Black Earth Economic Region".

\section{References}

1. N. E. Pokrovskij, Obratnaya migraciya $v$ usloviyah pandemicheskogo krizisa: vnegorodskie prostranstva Rossii kak resurs adaptacii, Sociologicheskie issledovaniya, 12, 54-64 (2020). Access mode: DOI 10.31857/S013216250010726-1

2. L. L. Rybakovskij, Ocenka vozmozhny $i$ neobhodimyh masshtabov privlecheniya immigrantov $v$ Rossiyu (2010)

3. K. V. Harchenko, Demograficheskij potencial kak resurs strategicheskogo razvitiya regionov i municipal'nyh obrazovanij, Srednerusskij vestnik obshchestvennyh nauk, 2 , 56-77 (2021). Access mode: DOI 10.22394/2071-2367-2021-16-2-56-77

4. O. L. Rybakovskij, Demograficheskij potencial: iz istorii ponyatiya, Narodonaselenie, 2, 17-25 (2019). Access mode: DOI 10.24411/1561-7785-2019-00012

5. A. I. Kuzmin, Osnovnye podhody $k$ ocenke demograficheskogo potenciala territorii, II Vserossijskaya nauchno-prakticheskaya konferenciya s mezhdunarodnym uchastiem, 183-187 (2016)

6. M. L. YAshina, Ocenka demograficheskogo potenciala municipal'nyh obrazovanij, Mezhdunarodnyj nauchno-issledovatel'skij zhurnal, 5-3(107), 86-91 (2021). Access mode: DOI 10.23670/IRJ.2021.107.5.080

7. Obrębalski Marek. Demographic potential in functional areas of the selected mediumsized cities in Poland and the Czech Republic, 11, 16-24 (2017)

8. W. Joe, A. Kumar, S. Rajpal, Swimming against the tide: economic growth and demographic dividend in India, Asian Population Studies, 14, 211-227 (2018). Access mode: https://www.tandfonline.com/doi/full/10.1080/17441730.2018.1446379 
9. M. Rostropowicz-Miśko, Women's labour migrations as a restrictive factor on Opole Silesia's demographic potential, according to own research, Problemy Polityki Społecznej, 27, 147-158 (2014)

10. I. B. Mamedov, Rol' migracionnyh processov v demograficheskom razvitii v evropejskih stranah, Uchenye zapiski Krymskogo federal'nogo universiteta imeni V.I Vernadskogo. Geografiya. Geologiya, 6 (2), 93-105 (2020)

11. M. A. Karceva, Migraciya v Rossii i social'no-ekonomicheskoe razvitie regionov: analiz vzaimnogo vliyaniya, Problemy prognozirovaniya, 4(181), 87-97 (2020)

12. V. A. Lapshov, Migraciya kak resurs social'no-ekonomicheskogo razvitiya sovremennogo obshchestva, Migraciya kak resurs social'no-ekonomicheskogo i demograficheskogo razvitiya: Sbornik statej, 146-155 (2019)

13. A. Yu. Lukyanova, Migraciya kak determenanta kadrovoj bezopasnosti regiona, Migraciya kak resurs social'no-ekonomicheskogo i demograficheskogo razvitiya: Sbornik statej, 48-51 (2019) 